\title{
Small and Medium Enterprises Facing Institutional Barriers in Kosovo
}

\author{
Florin Peci \\ Law Enforcement, Customs of Kosova, 10000 Prishtina, The Republic of Kosovo \\ Tel: 377-44-787-897Ｅ-mail: florinpeci@yahoo.com
}

Enver Kutllovci

Faculty of Economics, University of Prishtina, 10000 Prishtina, The Republic of Kosovo

Tel: 377-44-250-742Ｅ-mail: ekutllovci@hotmail.com

Qazim Tmava

Universum College, 10000 Prishtina, The Republic of Kosovo

Tel: 377-44-200-021 E-mail: qazimt1964@yahoo.com

Venet Shala

Fama College, 10000 Prishtina, The Republic of Kosovo

Tel: 377-44-379-753 E-mail: venetshala@hotmail.com

Received: November 8, $2011 \quad$ Accepted: December 8, $2011 \quad$ Published: February 1, 2012

doi:10.5539/ijms.v4n1p95 URL: http://dx.doi.org/10.5539/ijms.v4n1p95

\begin{abstract}
The purpose of this paper is to study in-depth the impact of formal and informal factors on the growth of small and medium enterprises (SMEs). Kosovo, as one of the last countries in transition characterized by difficult social and economic conditions, is used as a case study in this paper. The main institutional obstacles faced by SMEs in Kosovo that are involved in international trade will be analyzed from the perspective of the institutional theory developed by North (1990). The case study is based on in-depth interviews of firms in Kosovo, using an unstructured questionnaire, conducted in 2010. The paper's key findings show that informal activities caused by low levels of professional and ethics of officials in respective institutions, as well as poor enforcement of regulations, have significant impact on increasing transaction costs, which in turn represents a major obstacle to the further growth of SMEs.
\end{abstract}

Keywords: Growth, Institutional barriers, Small and medium enterprises (SMEs), Kosovo

\section{Introduction}

Scholars who have studied small and medium enterprises (SMEs) emphasize that in both developed and developing countries SMEs represent a key factor for economic growth, increased employment, the creation of a competitive market, technical and technological innovation, as well as other aspects of social and economic development (Acs and Audretsch, 1990; Johnson and Loveman, 1995). Because of the need to adjust to the new economic situation created by the process of transformation from the former socialist system toward a more competitive market system, the growth of SMEs is a challenge for less developed countries and countries in transition. The importance of SMEs after the eighties derives from the fact that 98 percent of the enterprises all over the world are considered as a generator of economic growth (Audretsch, 2007; World Bank Group, 2005; McMillan and Woodruff, 2002).

The growth of SMEs does not occur similarly in all countries. In countries in transition, different contextual obstacles impede the growth of firms; these factors include business environment factors, amongst which the most important are institutional ones. These impediments are present as a result of a hostile and unpredictable 
environment for doing business; an environment that is characterized by weak institutions and poor enforcement of laws, regulations and property rights, and these are present particularly in vulnerable post-war countries like Kosovo (Hoxha, 2009).

It should be emphasized that unpredictable obstacles, which affect negatively the growth of SMEs, characterize the transition process. Most of these evident obstacles are qualified as either formal obstacles, namely high levels of taxation (Hashi, 2001; Bukvić and Bartlet, 2001; Aidis 2005), overall business environment (Estrin et al., 2005; Bartlett and Prasinkar, 1995; Smallbone, 2002; Krasniqi 2007), legal framework (Smallbone and Welter, 2001b), or informal barriers, namely enforcement of property rights (Schaffer and Weder, 2001), and the networks of corruption (Johnson et al. 1997). To analyze the impact of both formal institutions (e.g. laws and regulations) and informal activities (e.g. red tape, bribery, corruption and others) on the development of entrepreneurship in the transitional environment, numerous researchers have used the institutional perspective based on the institutional theory (Feige, 1997; Van de Mortel, 2002; Aidis, 2006; North, 1990). Given the other factors that influence the development of entrepreneurship, there were efforts made by different authors to account for its positive contribution to economic growth, as well as for its negative, unproductive, and, furthermore, destructive effect (Baumol, 1990; Dallago, 1997; Foss and Foss, 2002).

As the last country in Europe to enter the transition, Kosovo is confronted with various obstacles, most of which are consequence of the previous socialist system and the inheritance of the war it went through in the late 1990s. These obstacles were only aggravated by the United Nations Administration Mission in Kosovo (UNMIK) after the war. Consequently, after gaining its independence in 2008, Kosovo remains characterized by high levels of insecurity, and in this respect it is a unique case because of the overall politically marginalized context (Hoxha, 2009).

SMEs make up about 98 percent of all enterprises in Kosovo, and represent thus a significant potential for its economic growth. As a consequence of the non-productive orientation of Kosovo's economy, the main sector is the sector of imports. The export sector has recently begun a rapid rise, especially in the export of goods, particularly of minerals. Nevertheless, exports cover only $10 \%$ of the overall imports. This is an important indicator of the possibilities for the SMEs to develop and penetrate the regional markets and beyond. However, unemployment in the country is between 40 and 50 percent of the active population capable of work, with a tendency to increase as a consequence of annual entrance of around 30,000 newcomers into the labor market (Riinvest, 2005).

It should be emphasized that even after the declaration of independence in 2008, SMEs in Kosovo continue to face institutional barriers and other obstacles created by the business environment, including complex and inefficient regulations, difficulties in access to financial resources, lack of professional skills, new technical and technological knowledge, as well as difficulties in selling goods and services to local, regional and international markets.

The study of Kosovo's case will attempt to provide new knowledge in the field, through a qualitative approach to the factors that affect institutions in the development and growth of SMEs. Findings obtained in this paper will deepen our understanding of the formal and informal barriers to institutions. This can then serve the government policy makers and the business community, in their efforts to create a stable institutional environment that is suitable for the growth of SMEs. In particular, the case of Kosovo adds to the broader analysis the dimension of obstacles caused by war and by international administration. The case of Kosovo can, therefore, serve as a useful example for other countries that are confronting similar difficulties and that have similar socio-economic situation.

\subsection{Research questions}

Given the hitherto summary of the purpose of this paper, two main questions arise:

1). How do institutional factors affect the growth and development of Kosovo SMEs involved in international trade?

2). What are the main barriers to formal and informal activities of SMEs involved in international trade?

\subsection{SMEs in international trade}

In Kosovo, the private sector consists of enterprises the majority of which are considered SMEs. The remaining enterprises are socially owned and operate with minimal capabilities. The latter are either in the process of being privatized or will be privatized in the future. The SME sector constitutes 98 percent of all the enterprises in Kosovo. The sector is organized in various forms, but it is dominated by family businesses, which at the same time represents a huge potential growth in the country (Riinvest, 2005). There are approximately 105,000 
registered businesses divided in micro enterprises that employ up to 10 employees, small and medium enterprises, while the rests are considered large enterprises. Of the total number of businesses that exist in Kosovo, more than 28000 companies are engaged in the import and export of goods in international trade (MTI, 2009). SME development in Kosovo is more concentrated in the sectors of trade and services, and less in production and export. This is due to the difficult conditions that are not conducive to the development of businesses, caused mainly by macroeconomic policies in place.

The economic development of Kosovo in the post-World War II began in conditions and circumstances of the socialist system that was applied in the former Yugoslav Federation. In this period Kosovo was a typical agrarian country with undeveloped industry, with agriculture participating with $70 \%$ in revenue, while industrial production participated with $30 \%$. Kosovo achieved the highest rate of economic growth and the most qualitative changes during the mid 70s, when it also gained a substantial autonomy. Thus, this economic growth was achieved during the period when Kosovo attained equal political status with other units of the Yugoslav federation.

In the late $80 \mathrm{~s}$, Kosovo's economy relied on the great number of companies producing semi-products. Industry and mining accounted for $47.5 \%$ of domestic product in Kosovo, fishing and agriculture for $20.8 \%$, commerce for $12 \%$, construction for $6.8 \%$ and transport and communication infrastructure for $4.5 \%$. Based on the data taken from Statistical Yearbook of the Statistical Office of Kosovo, Kosovo during this period exported its products to foreign markets, and export value went from 121 million up to 200 million Euros, which is considered the highest value at that time.

After the ongoing destruction of the economy of Kosovo, since 1990 until the end of war in 1999, the production in Kosovo became almost inexistent and traditional foreign markets for exports were lost. The largest part of the production which had export potentials capacity was destroyed, and, on the other hand, the new genuine export capacities did not develop.

Entrepreneurship in the former Yugoslavia has had its great momentum after functionaliziation of the law on enterprises in 1988, creating the basic conditions for the establishment of private businesses (Hoxha, 2009). Soon after, a large number of private enterprises were established in Kosovo as a result of the severe conditions to find employment in social ones. It is necessary to stress here that after the 90's Kosovo Albanians were dismissed from their work positions in state institutions, and the only way to survive was self-employment. This suggests that entrepreneurship of that time was more a result of repression by the Serbian regime (Hoxha, 2009). There is no clear picture of entrepreneurship and enterprise development during this time. Furthermore, a significant number of Kosovar businesses of this time operated informally, avoiding tax obligations to the power of the then authorities (Hoxha, 2009).

The violent administration of the previous regime in Kosovo before 1999, and then the 1999 war, has had major consequences for the SME sector and the economy. The reasons were numerous ranging from the political, economic and historical. Furthermore, very bad management of social enterprises after the war resulted in the destruction and inefficiency of the enterprises, paving the way for the immediate start of their privatization by the Kosovo Trust Agency (KTA). On the other hand, for many years, Kosovo was not part of regional initiatives aimed at liberalizing trade, mostly due to the unresolved political status. There was no significant Foreign Direct Investment (FDI) in Kosovo until 2005, as in many other countries in transition, which is a necessary condition in the wake of the economy and particularly for the growth of the manufacturing sector and exports. Informal economy is also a dimension which should be mentioned here (MTI, 2009). At this time, the conditions for growth and development of enterprises were very difficult. It should be noted also that the causes for this are inter-related and include the road infrastructure, access to credit and bank transactions of financial institutions, lack of general laws and regulations on the functioning of the state, high unemployment rate, the lack of experience in running the businesses, lack of regular supply of electricity, and others (Hoxha, 2009).

Kosovo, as a country that declared its independence quite recently (on February 17, 2008), inherited a myriad of problems from its recent past, which also relate to numerous institutional obstacles. Most of these obstacles result from the lack of experience of the newly produced staff with the low professional level in governmental institutions, lack of adequate laws and their uncertainty, as well as difficulties that result from ineffective implementation of applicable laws. In addition, SMEs in Kosovo continue to face institutional barriers and other obstacles created by the business environment, including complex and inefficient regulations, difficulties in accessing financial resources, lack of quality education, poor knowledge and lack of experience in the use of new technologies, and difficulties in placing the goods in local, regional and international markets. Even though Kosovo is a part of Central European Free Trade Agreement (CEFTA), Kosovo's SMEs have been marginalized 
from some regional countries like Serbia and Bosnia and Herzegovina, which are also part of CEFTA agreement. This is due to the unclear political situation and Serbia's desire to use this situation to discriminate the products produced by SMEs in Kosovo.

These indicators which represent the continuing obstacles to business activities will significantly damage the private sector in Kosovo. In particular, SMEs involved in international trade are facing problems in meeting the legal requirements to the respective institutions (Verwaal and Donkers, 2001). These problems cause while compliance costs are higher for small enterprises (Hudson and Godwin, 2000; Sandford et al., 1981).

\section{Theoretical framework}

Many scholars have investigated the different obstacles to SMEs, including those that occur in the transition economies (Estrin et al., 2005; Aidis and Estrin, 2006; Aidis 2002; Bukvić and Bartlett, 2001; Bartlett and Prasnikar, 1995; Hashi, 2001; Pissarides et al., 2003; Smallbone, 2002). Relevant for our particular case is the insight that the development of free trade and entrepreneurial activities may be hampered or reoriented to noneconomic activities as a result of informal activities created due to the absence of formal institutions. One from the most important authors in this field, Williamson (1985) declared the transaction costs as "costs of disagreement," which are not part of the cost of production. Moreover, two main elements according to Williamson (1979) are the "transaction" and the "costs." The transaction costs' theory aims at the general realization of transactions with minimum costs. The reduction of the transaction costs will be achieved through a better organization of formal rules, institutional laws and legal instructions, and other organizational forms of government enforcement (Williamson, 2000).

It is known that institutions in transitional countries do not perform well, and that they are fragile and weak in terms of designing and implementation of state policies. This certainly influences the economies of countries in transition, which are being followed with constraints of general continuity in the economic sector, and in particular, these obstacles are more pronounced for SMEs (Hashi, 2001). It should be especially noted that one of the biggest barriers for enterprises in transition countries is the low level of institutional development in the area of rules and conduct of business laws, as well as the business tax system (Aidis and Sauka, 2005). Such institutional policies are considered overcrowded for entrepreneurship and for the regular functioning of the businesses, and they often have a destructive role in the growth and performance of SMEs. This destructive role of the state institutions in the transition countries is expressed, among others, in the issuance of a considerable number of unnecessary rules and laws in terms of allocation of the activities of entrepreneurship and business operation. The excessive and inadequate overload of these formal rules causes an increase of informal activities, such as corruption and nepotism (Bartlett and Bukvić 2001; Smallbone and Welter 2001; Djankov et al, 2002).

However, there is no agreement in the entrepreneurship literature as to whether productive or unproductive entrepreneurship refers to activities only, or to the output of entrepreneurship (Sauka and Welter, 2007). This is a new conceptual framework introduced by Sauka (2008) that distinguishes between productive, unproductive and destructive entrepreneurship. Based on the work of Sauka (2008), it is therefore, the output on different levels "created" by entrepreneurship activities, which may have an impact on the performance of firms or its contribution to the growth of the economy.

The predominant role in creating and shaping the business environment necessary for the development of the SME sector belongs to institutions. Based on Estrin et al. (2005), institutions can influence the entrepreneurship and SME development, either by hampering the establishment of new firms, by lowering the total number of start-ups, or by hampering the growth of existing firms. Thus, according to Baumol (1990), the state, as the agency which has a crucial role in creating "the rules of the game" in shaping the business environment, should design the appropriate rules for stimulating the growth of productive entrepreneurship.

Besides the formal barriers, the informal ones can also hinder the growth of SMEs. The most important among them - particularly in the Kosovo's case - are those related to corruption and unofficial economy, and we will refer to them as barriers confronted by the firms as a consequence of low ethics of officials. One from the most important side effects of the over-regulation of the company sector, leads quite often to the evasion of regulation by entrepreneurs and in turn, to the consequent growth of the grey economy, as well as to their decisions to devote resources for influencing the regulatory environment in their own favour, thereby encouraging the so-called "unproductive entrepreneurship" (Baumol, 1990).

\section{Methodology}

By combining previously developed theories with new empirically derived insights (Yin, 1994), this paper aims to base itself on case studies, an approach that is especially appropriate in new topic areas. However, as a result 
of its application could be transcending the local boundaries of the investigated cases, capturing new layers of reality and developing novel insights that are practical, testable and empirically and theoretically valid (Eisenhardt, 1989; Ghauri, 2004; Tsoukas, 1989; Stuart et al., 2002). The aim of the case study is often to capture the uniqueness of a particular phenomenon, rather than to use it as a basis for wider generalization and to test existing theory. In this study, the findings are presented in a narrative approach, rather than framing them in terms of variable dependence and/or relationships, or in this line we should mention here that hermeneutic scientists go further than receiving results through statistical methods (Hammersley and Gomm, 2000).

True casual relationships are discovered by capable case researches (Hillebrand et al., 2001). Case studies create thick descriptions and rich understandings (Dyer and Wilkins, 1991) of phenomena in their natural settings (Dubois and Gadde, 2002; Yin, 1994). Case studies research, moreover, are not sampling research. Case studies try to understand the complexity of a single case (Stake, 1995), thus they are not investigated to understand other cases. It is diversity of cases that enhances the development of knowledge, when you are doing research on a group of case studies (Stake, 1995). The researcher through case studies can understand how and why things happen as they do (Miles and Huberman, 1994; Stuart et al., 2002; Yin, 1994). The amount of detailed information that the researcher collects about each case, is an important dimension of case study research methods.

In this paper, we used multiple case study approach. There is never an ideal number of cases of this qualitative action approach. According to Eisenhardt (1989), a good study is accomplished by 4-10 cases. It is understandable that a theory is difficult to be generated by few cases. On the other hand, theory with more cases will create a large volume of data, which is difficult to cope with. The amount of detailed information that the researcher collects about each case is an important dimension of case study research. The most information can be collected if some things are being held constant, and few cases investigated. Researching a case study implies the collection of unstructured data and its subsequent analysis.

An examination of five enterprises in trade, manufacturing and service sector was conducted, in line with the research questions. This in-depth examination involved semi structured and open-ended questions for identified respondents within each case study firm. In addition to that, a review of available historical data and cross-checking validation with other interviewees in each case was conducted. The theoretical generalization can be achieved even with this number of cases, if we can formulate the logical conclusions, these relationships should also hold for structurally similar cases (Hillebrand et al., 2001). Generalizations of theory could also be made by one case study, but a larger number of cases should augment external validity and help to guard against observer bias (Stuart et al., 2002).

The focus shifts to choosing the cases that are best suited for investigating the theory; this is done by treating each case as an individual study, rather than a sampling unit. By examining the findings under various conditions, cases complement each other, and thus address different aspects of the overall theory. The goal is that together the set of case studies will provide rich support for the theory (Johnston et al., 1999; Miles and Huberman, 1994) rather than each case being expected to be a representative of the whole population (Chetty, 1996).

Objectivity is a particular issue in a case study. How can we maintain the objectivity? How we can dissociate the researcher's own views from the previously cited narrative approach to present the findings? This issue is a primary concern, particularly in research that focuses on individual respondents/case studies. Multiple data sources were used to avoid the bias of individual respondents. The objectivity will be addressed through the above-described multi-faceted approach to data collection. This methodological approach is congruent with what was suggested by Coviello and McAuley (1999) resulting from their comprehensive review of the internationalization of small firms. Data collection methods should support these characteristics (bearing in mind that internationalization process is dynamic and holistic).

The five case companies reviewed in this paper belonged to different owners (this increased the findings' generalizability), they were oriented on different markets and did not exports or imports similar products. Two out of five firms were established before 1999; the other three were much younger. Each entrepreneur was initially contacted via the phone in order to obtain an appointment to carry out an in-depth interview which was held at their business premise. In-depth interviews were carried out with the entrepreneurs, and this was recorded (voice recorder). The recorded interviews are transcript and were analyzed. From this analyses certain conclusions and recommendation are prepared. 


\subsection{Brief companies' backgrounds}

\subsubsection{Company A}

Company A is a goods chain market, operating all over the country. It was founded in1996, and its products include much consumption goods starting from food, technology, cosmetics and others. Over the years, this company has experienced a sustainable growth that reaches an annual turnover of $€ 22$ million. It employs about 300 employees. It is formed as Limited Liability Company, and its preferred supplier market is EU, USA, CHN and the region of Balkans. These companies exports-import generally different goods, which have different value, large quantity, and different assortments of product. This company also uses some trade facilitation procedures provided by Kosovo customs, the goal of which is to develop the economy of Kosovo, like Customs Warehouse, Inward Processing, Temporary Importation, that means the company can import the goods in a country without paying the customs duty and VAT tax, until they bring in the free circulation or to re-export them.

\subsubsection{Company B}

This company is a producer of consumption goods. It began its activity in 2000. It is a commercial producer company with 60 employees. During the first years, this company focused its activities on importing. It imported machinery to which they started to produce consumption goods. It has an annual turnover of $€ 1$ million. It is a company which produces wide consumer goods, which have small value, large quantity, and it uses a simple technology to produce them. Company B has fulfilled all legal procedures. This company also benefited from EU funds for development. The company started to export immediately after they started to use the machinery. Export sales make up 30\% of total sales, of which approximately $90 \%$ goes to regional market like: Macedonia, Albania, etc. Company prefers regional market but also EU and Turkey even though, for the moment, the penetration to the EU market is impossible because of Hazard Analyze Critical Control Point- HACCP, and other quality standards.

\subsubsection{Company $\mathrm{C}$}

This is a service company. It was established in 1999. It employs 80 employers and has $€ 5$ million, annual turnover. It is a company that brings the last models of technology products to the local market; it also provides solid consultancy and maintenance for these products. It prefers regional, EU, USA, CHN markets. The IT sections goods are their main product. They are Hi-tech goods, which have large quantity, small value. In the beginning, the company began its activity with a small number of employees, who did not have any know-how about this activity, but in the meantime the company sent ten employers to Western countries to be upgraded professionally in this field (IT). After they returned, they used the knowledge that they got from their trip, to provide such services in Kosovo. And suddenly they managed to become one of the main leaders in their stream. Their clients are not only private ones, but also government institutions to whom they are delivering these services.

\subsubsection{Company D}

Company D is a trading company. It was founded as a limited liability company in 1995. It employs 153 employers with a preferred market in region, EU, Turkey and Asia. It has an annual turnover of $€ 10$ million, and the general goods are their main products. The goods are differently valued, they are in a large quantity, and in electronics branches. They began with a small market but by time, they were growing their employers and products. After 1999, they began the process from scratch, because the war of 1998-1999 destroyed all their facilities and achievements. In this beginning all that they had were the connections with the suppliers, who helped them to restart the activity in that way that they offer them payable goods (they had to pay them later). This was due to a trust that the suppliers had in them, because the demand was very high in Kosovo for all kinds of goods. This company managed to regain the market again, while increasing the number of employees and their turnover.

\subsubsection{Company E}

Company $\mathrm{E}$ is a Trade Company which has been formed as food-processing enterprise. It was established in 2002 , and it employs 38 people. The annual turnover of this company is $€ 1,3$ million. It exports-imports raw material for the goods, which are small valued, with a large quantity, and simple technology. Its market is regional. The main activity of the company is the collection, preservation, and processing of fruits and vegetables in canned food in thousand of tones per annum. Full-time workers and additional part-time workers (from 150-200), work especially during summer season, when the fruits and vegetables are collected and harvested. The main trading partners are regional like Albania, Montenegro, Serbia, and others. This company has invested in new machinery, which allows the company to produce more products. However, the major 
competitive advantage is the quality of these goods, which is unique among this region.

\section{The findings}

This research finds out some fields that companies have opinions about. Companies have fulfilled all procedures on regulations of customs and trade, based on customs and trade laws, which are obligatory to be fulfilled on day to day activity. The companies involved in international trade on export-import from a country to another, should submit a number of documentation such as custom's declaration, invoice, certificate of origin, phytosanitary certificate, and others.

1) The cases that this research had found that the requests for necessary documentation for the declaration of imported and exported goods, to fulfill the customs' procedures, are often unnecessary or redundant, very problematic, and unacceptable. Company $\mathrm{C}$ states that the "Requests are at most time unfulfilled, and they are not taken on consideration (...)most of it when, the goods are contracted and are worked with contract, on these cases customs does not take under consideration these kind of contracts". But also a part of them, understands them as acceptable and necessary, because some of the companies are not very sincere on their declaration of these documentation. Therefore, the request for additional documentation, will clarify the transactions of goods between external suppliers and local traders, based on Company $\mathrm{E}$ and $\mathrm{D}$ "the request for documentation in my opinion are necessary because of the business environment (...) even though they are a barrier to the efficiency of work, they are nevertheless necessary."

2) The post clearance procedures like authorizations, appeals, rejects, audits and others are also barriers to SMEs involved in international trade. The majority of case studies see them as barriers in their activities, because it raises the transaction cost, and it makes them uncompetitive. Based on Company A, B, C, D and E "Appeals and rejects should be submitted because on several cases we have a subjective approach from the Custom's Officials (The Customs Law is interpreted according to them, not as it is written), most of the times, this kind of approach is wrong, while thinking that the importer is escaping the tax duties (...), and some of the mistakes are not taken under consideration, those which are done without importers knowing." Especially when they comply for a procedure, as example raising the value of imported goods, even though they submitted the invoice, but the customs do not accept that, after it. They comply, it will be a very long time until the authorities give an answer. The Company A say that "While for the cross borders' points I have not good words, internal procedures, however, we notice that there is some effort toward improvement (...). For this time, the goods stays at the customs' Terminal, this causes every-day $€ 50$ for company."

3) Ethic of customs officials is also one of the barriers, to which the cases consider that this is one of the most significant barriers in their day-to-day activities. As far as the ethics of customs officials is concerned, the companies are not only worried about corruption, even though it is also present (according to them), but they also discuss other elements such as nepotism, low professional capacity, and appeal to authority. According to some, and as says by Company A "from [their] experience some of the officials do not belong there." During research of the cases, as ethics matters, they think that this has improved much more, but there is also space for continuous improvement. The officials in some cases don't care about the problematic of presentation of the documentation, especially due to lack of knowledge about trade and customs procedures.

4) The average time for clearance of goods is also one of the concerns for the traders in our cases. Most of them consider this time to be very long, which raises the transaction cost, and in most cases is very irrational. Company A, D and E say that "Only the time that is spent from the truck staying on the Customs Terminal, costs us circus turnover of 650.000 (...) if this wouldn't happened, we could raise the producing efficiency." According to them, "the average time for clearance should not be as long as 24 hours, which means that the whole documentation would be fulfilled during the day." Furthermore, they say that this average time is the longest in the region, but they said that they "would understand if anything lasted ever more than one day." Especially, our case study which deals with IT services, thinks that time is the most important factor of the IT activities; therefore, the delays of the procedures cost them more than other simple trades.

\section{The contribution of the paper}

For academic researchers, this paper provides novel results about a specific subject and this enhances our broad understanding about entrepreneurship. Our results are based on the analysis of five different case studies that include firms in the main economic sectors, namely manufacturing, trade and service. Our paper thus provides a contribution to qualitative research indicators which reflect the development of entrepreneurship and the growth of SMEs in transitional and marginalized countries. Thus, we consider the findings of this paper to be important, as they reflect on the formal and informal barriers, as well as their impact on economic development, within the context of the particular topic of SMEs in transitional countries engaged in international trade. 
For entrepreneurs, our findings provide a clear picture of descriptors of SME growth and of development of entrepreneurship. Therefore, entrepreneurs who intend to establish their own business can use the results of our paper to evaluate their ambitions in regard to relevant factors affecting the growth and development of enterprises presented in the model of this paper and for deciding afterward on whether they will establish a particular business of their own.

For policy makers this paper provides knowledge which presents a good basis for drafting policy recommendations. From discussions and interpretations of the in-depth interviews, policy makers can understand which are the most pressing obstacles that negatively affect the growth and development of enterprises, and may then take the steps necessary for the elimination of these obstacles.

\section{Discussion and conclusion}

As mentioned in the introduction, the aim of this study was to explore institutional formal and informal factors that influence the growth of SMEs involved in the international trade, especially given Kosovo's context as a marginalized country. The influence that these factors have, in principle, on the growth of SMEs is very high. This is evident to the discussion of our case studies. Factors such as high taxes, fiscal policy, general environment, approach on regional and international markets, etc. represent significant barriers to Kosovo SMEs. These companies, in particular, mention institutional factors which in different ways prevent their growth on a daily basis. It is worth mentioning formal institutional aspects mentioned in the SMEs activities which deal with export-import of the goods. The companies of the case studies note that authorization issues, licenses, different certificates that need to be issued from respective institutions often take time and are unclear, especially that the institutions do not have a clear perspective on who is responsible for the documentations field, which is required for SMEs functioning on international trade.

In addition to the formal barriers, our analysis also reveals certain informal barriers. Our case studies emphasize more the customs' evaluation, as not in right form of implementing of law. According to this, the respondents think that there is a subjectivism on this issue. According to them, there are often mistakes, as a result of lack of knowledge for the trade procedures which costs them such problems. Though they had to understand for the aimless mistakes, and not take them as intentional mistakes of the traders. This destructive way, is enabling many custom's officials to violate the ethic code and to implement the law on their accordance. In addition, the lack of professionalism of the customs officials and lack of work knowledge often causes surplus costs to the importers and inefficiency in their day-to-day activity. Case studies note that information on time on the trade and customs procedures on the regulations change, authorizations and others, are typical cases of barriers of their activity.

This study is a wealthy point to the scientific literature over the growth barriers of the SMEs involved in international trade, while exploring institutional factors, in particular. The study fulfills a gap on the present research focused in the transition and marginalized places. Our result shows that it is a similarity of the growth barriers of SMEs in Kosovo, according to informal and formal factors on every sector of SMEs in international trade. These factors are burdening the growth of SMEs. The role of informal factors is particularly noteworthy, as they are present on the day-to-day activity. In the future, it would be preferable that the importance should be directed toward rightly implementing the law on the side of the officials and respecting the ethic code of their work.

As in any research work, this paper also had its own limitations. These were due to some facts that covered this research all the time. The first one is that the cases were conducted in a single point of time, which may cause potential risk due to respondent's point of view, for the most important things that they saw in that time. The second major limitation is that in-depth case study research in general has a small number of companies, a quantity that does not validate the findings. The third limitation is that the companies taken as examples are not seen as multi format SMEs but only as indicative of SMEs more widely. Another (fourth) limitation is that only SMEs are involved into the international trade. Lastly, we include only the external factors of SMEs, not internal ones. Based on this, future studies should concentrate in quantitative methods also, when they study the firm's growth in marginalized countries, especially institutional factors, and take under consideration the internal indicators that influence the firm's growth, as internal factors are.

Besides the above-mentioned limitations, we think that the interpretation of the interviews of the five case studies presented in this paper is important to understand the way in which firms operate in transition process contexts, and we hope that the findings will further serve as a theoretical and practical contribution on the growth study of the firm. 


\section{References}

Acs, Z., and Audretsch, D. (1990). Innovation and small firms. Cambridge: MIT Press.

Aidis, R. (2005). Institutional barriers to small- and medium-sized enterprise development in transition countries. Small Business Economics, 25(4), 305 - 318. http://dx.doi.org/10.1007/s11187-003-6463-7

Aidis, R., and Estrin, S. (2006). Institutions, networks and entrepreneurship development in Russia: An exploration. Discussion Paper Series, IZA, DP No. 2161.

Audretsch, D. B. (2007). The Entrepreneurial Society. Oxford: Oxford University Press. http://dx.doi.org/10.1093/acprof:oso/9780195183504.001.0001

Bartlett, W., and Bukvić, B. (2001). Barriers to SME growth in Slovenia. MOCT-MOST. Economic Policy in Transition Economies, 11(2), 177-195. http://dx.doi.org/10.1023/A:1012206414785

Bartlett, W., and Prasnikar, J. (1995). Small firms and economic transformation in Slovenia. Communist Economies and Economic Transformation, 7(1), 81-101. http://dx.doi.org/10.1080/14631379508427812

Baumol, W. (1990). Entrepreneurship: Productive, Unproductive, and Destructive. Journal of Political Economy. 98(5), 893 - 921. http://dx.doi.org/10.1086/261712

Bohata, M., and Mladek, J. (1999). The Development of the Czech SME Sector. Journal of Business Venturing, 14(5-6), 461 - 473. http://dx.doi.org/10.1016/S0883-9026(98)00025-1

Chety, S. (1996). The Case Study Method for Research in Small and medium Sized Firms. International Small Business Journal, 15 (1): 73-85. http://dx.doi.org/10.1177/0266242696151005

Coviello, N., and Munro, H. (1994). Growing the Entrepreneurial Firm: Networking for International Market Development. Journal of Marketing, 29, (7), 49-61.

Dallago, B. (1997). The Economic System, Transition and Opportunities for Entrepreneurship. Chapter 7, pp. 103-124 in Entrepreneurship and SMEs in Transition Economies, The Visegrad Conference. Paris: OECD.

Djankov, S., R. La Porta, F. Lopez-de-Silanes, and A. Shleifer. (2002). The Regulation of Entry. The Quarterly Journal of Economics, 67, 1 - 37. http://dx.doi.org/10.1162/003355302753399436

Dubois, A., and Gadde, L. (2002). Systematic Combining: An Abductive Approach to Case Research. Journal of Business research, 55 (7), 553-60. http://dx.doi.org/10.1016/S0148-2963(00)00195-8

Dyer, G., and Wilkins, A. (1991). Better Stories, not Better Constructs, to Generate Better Theory: A Rejoinder to Eisenhardt. Academy of Management Review, 16 (3), 613-19.

Eisenhardt, K. M. (1989). Building Theories from Case Study Research. Academy of Management Review, 14 (4), 532-50.

Estrin, S., Meyer, K., and Bytchkova, M. (2005). Entrepreneurship in transition economies. In The Handbook of Entrepreneurship. Casson, M., Yeung, B., Basu, A. and Wadeson, N. (eds.). London: Oxford University Press.

Feige, E. (1997). Underground Activity and Institutional Change: Productive, Protective, and Predatory Behavior in Transition Economies. In Tilly, C, J. Nelson \& L. Walker (eds.), Transforming Communist Political Economies. Washington DC: National Academy Press, 21-34.

Foss, K., and K.J. Foss. (2002). Economic Organisation and the Trade-offs Between Productive and Destructive Entrepreneurship. In Foss, N. and Klein, P. (eds.), Entrepreneurship and the Firm: Austrian Perspectives on Economic Organisation. Northampton, Mass.: Edward Elgar, pp. 102-127.

Franicevic, V., and Bartlett, W. (2001). Small firm networking and economies in transition: An overview of theories, issues and policies. Zagreb International Review of Business and Economics, 4(1), 63-89.

Ghauri, P. (2004). Designing and Conducting Case Studies in International Business Research. Handbook of Qualitative Research Methods for International Business, Rebecca Marchan-Piekkari and Catherine Welch, eds. Cheltenham, UK: Edward Elgar, 109-24.

Hammersley, M., and Gomm, R. (2000). Introduction. In R. Gomm, M. Hammersley, \& P. Foster (Eds.). Case study method: Key issues, key texts (pp. 1-16). London: Sage.

Hashi, I. (2001). Financial and Institutional Barriers to SME Growth in Albania: Results of an Enterprise Survey. MOCT_MOST, 11(3), 221 - 238. http://dx.doi.org/10.1023/A:1013157127524

Hillebrand, B., Kok, A.V.R., and Biemans, W. (2001). Theory-Testing Using Case Studies: A Comment on Johnston, Leach, and Liu. Industrial Marketing Management, $30 \quad$ (8), 651-7. 
http://dx.doi.org/10.1016/S0019-8501(00)00115-2

Hoxha, D. (2009). Barriers to doing business in Kosova: an institutional approach. International Journal on Entrepreneurship and Small Business, 8 (2), 186-199. http://dx.doi.org/10.1504/IJESB.2009.024376

Hudson, J., and M. Godwin. (2000). The Compliance Costs of Collecting Direct Tax in the U.K.: An Analysis of PAYE and National Insurance. Journal of Public Economics, 77(1), 29-44. http://dx.doi.org/10.1016/S0047-2727(99)00088-2

Johnson, S., and Loveman, G. (1995). Starting Over in Eastern Europe: Entrepreneurship and Economic Renewal. Cambridge: Harvard Business School Press.

Johnson, S., Kaufmann, D., and Shleifer, A. (1997). The Unofficial Economy in Transition. Brookings Papers on Economic Activity, Washington D.C.

Johnston, W., Leach, M., and Liu, A. (1999). Theory Testing Using Case Studies in Business-to-Business Research. Industrial Marketing Management, 28 (3), 201-13. http://dx.doi.org/10.1016/S0019-8501(98)00040-6

Krasniqi, B. (2007). Barriers to entrepreneurship and SME growth in transition: the case of Kosova. Journal of Developmental Entrepreneurship, 12(1), 71 - 94. http://dx.doi.org/10.1142/S1084946707000563

Lawrence, S. et al. (2001). Persistence of Web References in Scientific Research. Computer, 34, 26-31. http://dx.doi.org/10.1109/2.901164

McMillan, J., and Woodruff, C. (2002). The Central Role of Entrepreneurs in Transition Economies. Journal of Economic Perspectives, 16 (3), 153-170. http://dx.doi.org/10.1257/089533002760278767

Miles, M., and Huberman, M. (1994). Qualitative Data Analysis: An Expanded Sourcebook. London: Sage.

MTI. (2009). Trade Policy of Kosovo. Ministry of Trade and Industry, Prishtine.

North, D. C. (1990). Institutions, Institutional Change and Economic Performance. Cambridge: Cambridge University Press.

Pissarides, F., Singer, M., and Svenjar, J. (2003). Objectives and constraints of entrepreneurs: Evidence from small and medium size enterprises in Russia and Bulgaria. Journal of Comparative Economics, 31(3), 503-531. http://dx.doi.org/10.1016/S0147-5967(03)00054-4

Riinvest Institute for Development Research (2005). SME Development in Kosova, Research report. Prishtine. Riinvest.

Sandford, C. T., and J. Hasseldine (1992). The Compliance Costs of Business Taxes in New Zealand. Wellington: Institute of Policy Studies, Victoria University.

Sandford, C. T., M. Godwin, P. J. W. Hardwick and M. I. Butterworth. (1981). Costs and Benefits of VAT. London: Heinemann Educational Books.

Sauka, A. (2008). Productive, Unproductive and Destructive Entrepreneurship: A Theoretical and Empirical Exploration. William Davidson Institute Working Paper, Number 917.

Sauka, A., and F. Welter (2007). Productive, Unproductive and Destructive Entrepreneurship in an Advanced Transition Setting: The Example of Latvian Small Enterprises. In M. Dowling und J. Schmude (eds.). Empirical Entrepreneurship in Europe: New Perspectives. Cheltenham, UK: Edward Elgar, 87-105.

Schaffer, M., and Weder, B. (2001). Firm size and the business environment: Worldwide survey results. International Finance Corporation, Discussion Paper, No. 4.

Smallbone, D. (2002). Institutions, administrative reform and SME development in transition economies: Some policy issues. Paper presented at Conference on Economic Development and Reconstruction Policies in SEE, Dubrovnik, 25-28 April.

Smallbone, D., and F. Welter. (2001b). The Role of Government in SME Development in Transition Countries. International Small Business Journal, 19(4), 63-77. http://dx.doi.org/10.1177/0266242601194004

Smallbone, D., and Welter, F. (2001). The distinctiveness of entrepreneurship in transition economies. Small Business Economics, 16(4), 249 - 262. http://dx.doi.org/10.1023/A:1011159216578

Smallbone, D., and Welter, F. (2006). Conceptualizing entrepreneurship in a transition context. International Journal of Entrepreneurship and Small Business, 3 (2), 190-206. http://dx.doi.org/10.1504/IJESB.2006.008928

Smallbone, D., F. Welter, N. Isakova and A. Slonimski. (2001). The Contribution of Small and Medium Enterprises to Economic Development in Ukraine and Belarus: Some Policy Perspectives. Most, 11(3), 253 - 
273. http://dx.doi.org/10.1023/A:1013113312503

Smith, Joe. (1999). One of Volvo's core values. [Online] Available: http://www.volvo.com/environment/index.htm (July 7, 1999).

Stake, R. E. (1995). The Art of Case Study Research. Thousand Oaks: Sage Publications.

Strunk, W., Jr., \& White, E. B. (1979). The elements of style. (3rd ed.). New York: Macmillan, (Chapter 4).

Stuart, I., McCutcheon, D., Handfield, R., McLachlin, R., and Samson D. (2002). Effective Case Research in Operations Management: A Process Perspective. Journal of Operations Management, 20 (5), 419-33. http://dx.doi.org/10.1016/S0272-6963(02)00022-0

Tsoukas, H. (1989). The Validity of Idiographic Research Explanations. Academy of Management Review, 14 (4), 551-61

Van de Mortel, E. (2002). An Institutional Approach to Transition Processes. Hants, UK: Ashgate.

Van der Geer, J., Hanraads, J. A. J., \& Lupton R. A. (2000). The art of writing a scientific article. Journal of Scientific Communications, 163, 51-59.

Verwaal, E., and Donkers, B. (2003). Customs - related Transaction Costs, Firm Size and International Trade Intensity. Small Business Economics, 21, 257-271. http://dx.doi.org/10.1023/A:1025702520091

Williamson, O. E. (1979). Transaction Cost Economies: The Governance of Contractual Relations. Journal of Law and Economics, 22, 3-61. http://dx.doi.org/10.1086/466942

Williamson, O. E. (2000). The New Institutional Economics: Taking Stock, Looking Ahead. Journal of Economic Literature, 38(3), 595 - 613. http://dx.doi.org/10.1257/jel.38.3.595

Williamson, O. E. (1985). The Economic Institutions of Capitalism. New York: The Free Press.

World Bank (2005). A better investment climate for everyone: World Development Report 2005. New York: The World Bank and Oxford University Press.

Yin, R.K. (1994). Case Study Research Design and Methods. London: Sage. 
Table 1. Companies' profiles

\begin{tabular}{|c|c|c|c|c|c|}
\hline Details of the Case Study & Company A & Company B & Company $\mathrm{C}$ & Company D & Company E \\
\hline $\begin{array}{l}\text { Start of import-export } \\
\text { activity }\end{array}$ & 1996 & 2000 & 1999 & 1995 & 2002 \\
\hline Number of employees & 300 & 60 & 80 & 153 & 38 \\
\hline $\begin{array}{l}\text { Annual trade turnover ( } € \text { in } \\
\text { millions) }\end{array}$ & 22 & 1 & 5 & 10 & 1.3 \\
\hline $\begin{array}{l}\text { Legal Responsibility of } \\
\text { Business }\end{array}$ & LLC & $\begin{array}{l}\text { Trade \& manuf. } \\
\text { company }\end{array}$ & Service company & LLC & $\begin{array}{l}\text { Trade \& manuf. } \\
\text { company }\end{array}$ \\
\hline Market Preferred & $\begin{array}{c}\text { EU, USA, } \\
\text { CHN }\end{array}$ & EU, USA, CHN & Regional, EU & $\begin{array}{c}\text { EU, Regional, } \\
\text { Turkey, Asia }\end{array}$ & Regional \\
\hline $\begin{array}{l}\text { Type of goods to } \\
\text { import-exporter }\end{array}$ & $\begin{array}{l}\text { Different } \\
\text { goods }\end{array}$ & $\begin{array}{l}\text { Consumption } \\
\text { goods }\end{array}$ & Hi-tech goods & Different goods & $\begin{array}{c}\text { Raw material for } \\
\text { production }\end{array}$ \\
\hline $\begin{array}{l}\text { Characteristics of goods } \\
\text { (quantity, value, technology, } \\
\text { etc.). }\end{array}$ & $\begin{array}{l}\text { High value of } \\
\text { goods, The } \\
\text { small amount, } \\
\text { Modern } \\
\text { technology }\end{array}$ & $\begin{array}{l}\text { Low value of } \\
\text { goods, } \\
\text { Large amount, } \\
\text { Modern } \\
\text { technology }\end{array}$ & $\begin{array}{l}\text { High value of } \\
\text { goods, Large } \\
\text { amount, } \\
\text { Know-how } \\
\text { technology }\end{array}$ & $\begin{array}{l}\text { Different value } \\
\text { Large amount, } \\
\text { Modern } \\
\text { technology }\end{array}$ & $\begin{array}{l}\text { Low value of } \\
\text { goods, Large } \\
\text { amount } \\
\text { Simple } \\
\text { Technology }\end{array}$ \\
\hline $\begin{array}{l}\text { The general application } \\
\text { procedures. (trade and } \\
\text { customs) }\end{array}$ & $\begin{array}{l}\text { Institutional } \\
\text { barriers }\end{array}$ & $\begin{array}{l}\text { Institutional } \\
\text { barriers }\end{array}$ & $\begin{array}{l}\text { Institutional } \\
\text { barriers }\end{array}$ & $\begin{array}{l}\text { Institutional } \\
\text { barriers }\end{array}$ & $\begin{array}{l}\text { Institutional } \\
\text { barriers }\end{array}$ \\
\hline $\begin{array}{l}\text { Requests for the necessary } \\
\text { documentation for the } \\
\text { clearance of customs } \\
\text { procedures }\end{array}$ & $\begin{array}{l}\text { Necessary, } \\
\text { The oversized, } \\
\text { Problematic }\end{array}$ & $\begin{array}{l}\text { Necessary, } \\
\text { The oversized, } \\
\text { Problematic }\end{array}$ & $\begin{array}{c}\text { OK } \\
\text { The oversized }\end{array}$ & $\begin{array}{l}\text { Unacceptable } \\
\text { The oversized, } \\
\text { Problematic }\end{array}$ & $\begin{array}{c}\text { OK } \\
\text { The oversized }\end{array}$ \\
\hline $\begin{array}{l}\text { Post- documentary customs } \\
\text { procedure } \\
\text { (complaints, audits, } \\
\text { authorization) }\end{array}$ & $\begin{array}{l}\text { Acceptable } \\
\text { Remarks }\end{array}$ & $\begin{array}{c}\text { Acceptable } \\
\text { Large remarks }\end{array}$ & $\begin{array}{l}\text { Unacceptable } \\
\text { Remarks }\end{array}$ & $\begin{array}{l}\text { Unacceptable, } \\
\text { large Remarks }\end{array}$ & $\begin{array}{l}\text { Acceptable, } \\
\text { OK }\end{array}$ \\
\hline Ethics of customs officials & Weak & Weak & Weak & $\begin{array}{l}\text { Large Remarks, } \\
\text { Poor }\end{array}$ & $\begin{array}{c}\text { Note, } \\
\text { Acceptable }\end{array}$ \\
\hline Trade Facilitation & $\begin{array}{l}\text { Necessary } \\
\text { change of } \\
\text { policy }\end{array}$ & $\begin{array}{l}\text { Necessary } \\
\text { change of } \\
\text { policy }\end{array}$ & $\begin{array}{c}\text { Necessary } \\
\text { change of policy }\end{array}$ & $\begin{array}{c}\text { Necessary } \\
\text { change of policy }\end{array}$ & $\begin{array}{c}\text { Necessary } \\
\text { change of policy }\end{array}$ \\
\hline $\begin{array}{l}\text { The average time needed to } \\
\text { clearance customs procedure }\end{array}$ & $\begin{array}{l}\text { Long, } \\
\text { Improve }\end{array}$ & $\begin{array}{l}\text { Long, } \\
\text { Improve }\end{array}$ & $\begin{array}{l}\text { Long, } \\
\text { Improve }\end{array}$ & $\begin{array}{l}\text { Long, } \\
\text { Improve }\end{array}$ & $\begin{array}{l}\text { Average, } \\
\text { Improve }\end{array}$ \\
\hline
\end{tabular}


Table 2. Summary of findings

\begin{tabular}{|c|c|c|c|c|c|}
\hline Main problems & Company A & Company B & Company $\mathrm{C}$ & Company D & Company E \\
\hline $\begin{array}{l}\text { Trade and } \\
\text { customs barriers }\end{array}$ & $\begin{array}{l}\text { Fiscal policy High } \\
\text { taxes }\end{array}$ & $\begin{array}{c}\text { Government } \\
\text { agencies Fiscal } \\
\text { policy } \\
\end{array}$ & $\begin{array}{c}\text { Government } \\
\text { agencies High } \\
\text { taxes } \\
\end{array}$ & $\begin{array}{c}\text { High taxes } \\
\text { Fiscal policy }\end{array}$ & $\begin{array}{c}\text { Government } \\
\text { agencies Fiscal } \\
\text { policy } \\
\end{array}$ \\
\hline $\begin{array}{l}\text { Institutional } \\
\text { Barriers }\end{array}$ & $\begin{array}{c}\text { Government } \\
\text { agencies Financial } \\
\text { resources }\end{array}$ & $\begin{array}{l}\text { High taxes } \\
\text { Financial } \\
\text { resources }\end{array}$ & $\begin{array}{l}\text { Fiscal policy } \\
\text { Financial } \\
\text { resources }\end{array}$ & $\begin{array}{l}\text { Financial } \\
\text { resources } \\
\text { Government } \\
\text { agencies }\end{array}$ & $\begin{array}{l}\text { Financial } \\
\text { resources } \\
\text { High taxes }\end{array}$ \\
\hline $\begin{array}{l}\text { 1) the formal } \\
\text { aspect }\end{array}$ & $\begin{array}{c}\text { Different } \\
\text { Certificates } \\
\text { (veterinary, } \\
\text { phytosanitary, and } \\
\text { origin) } \\
\text { Different Licenses } \\
\text { Bank guarantees }\end{array}$ & $\begin{array}{c}\text { Different } \\
\text { Licenses, } \\
\text { Different } \\
\text { Certificates } \\
\text { (veterinary, } \\
\text { phytosanitary, and } \\
\text { origin) Bank } \\
\text { guarantees } \\
\end{array}$ & $\begin{array}{c}\text { Different } \\
\text { Certificates } \\
\text { (veterinary, } \\
\text { phytosanitary, and } \\
\text { origin) } \\
\text { Bank guarantees }\end{array}$ & $\begin{array}{c}\text { Different } \\
\text { Licenses, } \\
\text { Different } \\
\text { Certificates } \\
\text { (veterinary, } \\
\text { phytosanitary, and } \\
\text { origin) Bank } \\
\text { guarantees } \\
\end{array}$ & $\begin{array}{c}\text { Different } \\
\text { Licenses, } \\
\text { Different } \\
\text { Certificates } \\
\text { (veterinary, } \\
\text { phytosanitary, and } \\
\text { origin) Bank } \\
\text { guarantees } \\
\end{array}$ \\
\hline 2) Informal aspect & $\begin{array}{c}\text { Estimates } \\
\text { Ethics of customs } \\
\text { officials } \\
\text { Costs of transport }\end{array}$ & $\begin{array}{c}\text { Costs of transport } \\
\text { Ethics of customs } \\
\text { officials } \\
\text { Estimates }\end{array}$ & $\begin{array}{l}\text { Ethics of customs } \\
\text { officials } \\
\text { Costs of transport } \\
\text { Estimates }\end{array}$ & $\begin{array}{l}\text { Ethics of customs } \\
\text { officials } \\
\text { Costs of transport } \\
\text { Estimates }\end{array}$ & $\begin{array}{c}\text { Costs of transport } \\
\text { Ethics of customs } \\
\text { officials } \\
\text { Estimates }\end{array}$ \\
\hline $\begin{array}{l}\text { The compliance } \\
\text { costs }\end{array}$ & High & High & Moderate & High & Moderate \\
\hline $\begin{array}{l}\text { Information on } \\
\text { trade and customs } \\
\text { procedures }\end{array}$ & $\begin{array}{l}\text { Late } \\
\text { Weak }\end{array}$ & $\begin{array}{l}\text { Weak } \\
\text { Late }\end{array}$ & $\begin{array}{l}\text { Late } \\
\text { Weak }\end{array}$ & $\begin{array}{l}\text { Late } \\
\text { Weak }\end{array}$ & $\begin{array}{l}\text { Weak } \\
\text { Late }\end{array}$ \\
\hline $\begin{array}{l}\text { Professionalism } \\
\text { of customs } \\
\text { officials }\end{array}$ & Low & Middle & Middle & High & Middle \\
\hline
\end{tabular}

